International Journal of Health Sciences
Available online at http://sciencescholar.us/journal/index.php/ijhs
Vol. 3 No. 2, August 2019, pages: $38 \sim 43$
e-ISSN: 2550-696X, p-ISSN: $2550-6978$
https://doi.org/10.29332/ijhs.v3n2.329

\title{
The Brain and Learning on Initial Students
}

Ana Lucia Vinueza Reina a
Article history: Received 18 December 2018, Accepted: 30 April 2019, Published: 30 August 2019
Correspondence Author a ${ }^{\text {a }}$ Abstract
Thessark
Brain, functioning and the relationship it has with learning in students in the
initial stage. It addresses the different functions that the brain organ fulfills
within the human body and how it has the ability to respond to the surrounding
environment of each individual depending on the stimuli it receives from the
environment.

.

\section{Keywords}

brain functions;

cognitive processes;

creativity;

environment;

playfulness;

e-ISSN: 2550-696X, p-ISSN: 2550-6978 ๑Copyright 2019. The Author.

SS Journals Published by Universidad Técnica de Manabí.

This is an open-access article under the CC BY-SA 4.0 license

(https://creativecommons.org/licenses/by-sa/4.0/)

\section{Contents}

Abstract

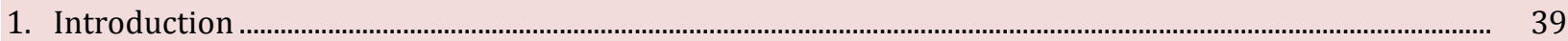

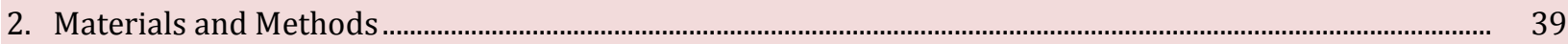

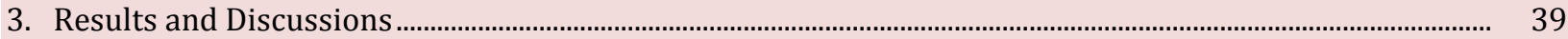

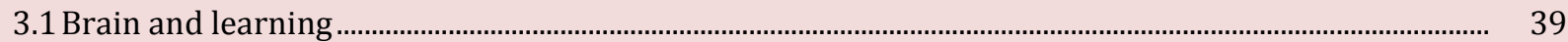

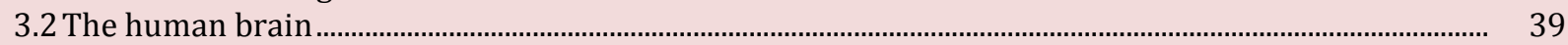

3.3 Creative and playful brain

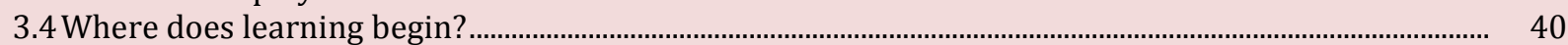

3.5 Influence of the environment for learning ……............................................................................................. 40

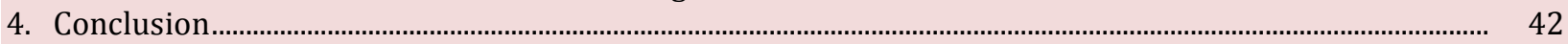

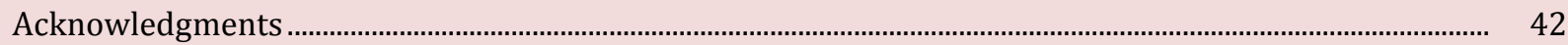

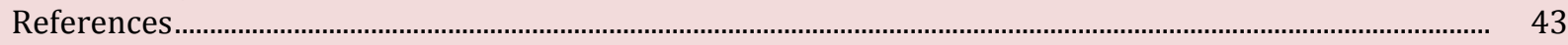

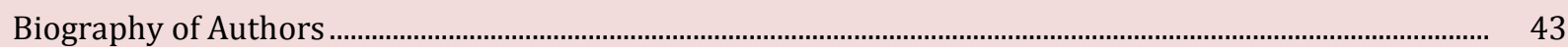

a Pontificia Universidad Católica del Ecuador, Portoviejo, Ecuador 


\section{Introduction}

The brain is related to learning, it is necessary to know its functions in the body as an organ of the human body, it has a weight of 1300 to $1400 \mathrm{~g}$, is the center of the nervous system and is made up of cells. It is located inside the skull, is responsible for different functions; controls and regulates actions and reactions, is able to organize the information it receives from the medium, analyze the data and respond to the actions.

It is necessary to know how the human brain learns?, How the medium can influence learning ?, How are the strategies used in learning assimilated?

These functions allow students with the greater or lesser intellectual capacity to achieve the objective equally, understanding that learning is a process that influences behavior and consolidates the behavior of each individual. It arises as has result of the experiences that are stored in the brain, those that configure the way of perceiving, thinking and planning the surrounding reality.

The research analyzes the importance of playfulness and creativity among the human brain organ and how these activities help in the development of creativity using them to configure active and effective learning.

\section{Materials and Methods}

The research was qualitative because it was necessary to describe the most relevant characteristics of the subject with theoretical foundation, so it was very important to analyze the information extracted from various sources that allowed us to give way to the use of bibliographic and descriptive sources.

The study is of an analysis-synthesis nature, a narrative and summary study of the theoretical foundations of the article was carried out in order to build new bibliographic knowledge because the development of the study was supported with texts and data sources separated from the internet.

\section{Results and Discussions}

\subsection{Brain and learning}

It can be emphasized that learning is a constructive process that requires the proper integration of information stored in the brain, which is vitally important in mind-body coordination. Jensen (2004), expresses that this organ by nature is designed to process and retain data that has meaning and meaning for the individual, from this the construction of knowledge arises since he is responsible for elaborating meanings of giving interpretation to what each day It is learned, has the ability to create and seek new alternatives or communication routes between control centers and specific processes.

Learning is genetically programmed and there are principles that allow the system to achieve results, making the best of itself, making use of brain flexibility probably inherited from the primitive elements within the evolution on the face of the earth, since it can be noted that all species, however elementary they may be They have the capacity to develop responses to their surroundings (Goodin, 2013; Mendoza et al., 2019; Mahendra, 2016).

\subsection{The human brain}

It has known to all, that the first 48 months of life are vital for brain development; therefore, many of the researchers indicate that the experience that children can acquire in this period is what determines the form of behavior of a person. Salinas (2018), refers to the brain stating that this is the most complex organ and changes from one individual to another despite having the same amount of neurons at birth

Understanding in this way that the human brain has a complex structure to explain, but specific functions correctly organized to perform specific actions at times when the information is evoked. Velásquez (2009), refers to this, saying that it is a biological and social organ that is responsible for relating thought to intuition,

Reina, A. L. V. (2019). The brain and learning on initial students. International Journal of Health Sciences, 3(2), 38-43. https://doi.org/10.29332/ijhs.v3n2.329 
imagination, playfulness, writing, consciousness and an infinite number of other processes, thanks to the capacity it has of Respond to the stimuli you receive from the environment.

The aforementioned suggests the importance of this organ and points out that the more knowledge, the greater the intelligence in the learning process, since the greater the neural connections, the greater the synapse and in this case it will give more learning.

\subsection{Creative and playful brain}

Creativity and play are undoubtedly one of the children's own abilities and in this process; the brain performs actions such as ordering and executing those actions (Martinez et al., 2019). Refers to the game as an indispensable tool for life. Itself because through it the child freely expresses and manifests happiness in a spontaneous way, during this event he discovers his personality and manages to easily relate to others regardless of cultural traits, integrates to the adult world by developing creativity and imagination and more skills that the child acquires through play.

The game gives the freedom to express happiness spontaneously, during the activities the children manage to establish a relationship with their peers, thus developing interpersonal intelligence. On the other hand, this activity is defined as being freely executed and many feelings can be expressed and it is also a means to develop the evolutionary process where the child experiment with the outside world by improving their socialization and communication (Campoverde, 2016; Iriani et al., 2018; Mustika \& Harini, 2017).

The game can provide many benefits to children and this, in turn, allows you to move to an imaginative world built by themselves using creativity, it is such an important tool that when applied in classrooms. They learn actively and dynamically.

\subsection{Where does learning begin?}

Responding where learning begins or if you ever stop learning is easy to give a specific answer because learning arises because of who we are and what we genetically and culturally inherit from parents. Glejzer (2015), mention that the human being from birth learns, to walk, talk, play, have feelings and control emotions, ride a bike, solve problems or perform complex calculations and that all these influences all aspects of human life, tastes, fears, opinions, and beliefs.

It can have emphasized that learning is an activity that develops individually within the context where the person develops and the stimuli that he receives from his environment be it familiar and social. Van Leer (2013), refers that in the explanation of Piaget (1952/1963), first the child gropes with the hand, but gradually the coordination between the eye and the limb arises, that there is greater congruence between what the child sees and what he reaches with his hand.

The coordination of the thumb and index finger continues to improve until the child can safely reach an object and take it. The center of attention was directed to the interaction of the individual, with the physical world seen in this way it is understood that for Piaget the children configure, their learning in a sensory way and at the same time they use the hand to bring objects to their mouth it configures the coordination manual oculus (Van Leer 2013; Alava \& Martinez, 2019; Suarez et al., 2019). Expresses what Vygotsky said (Vygotsky, $1978,1934 / 1987)$ the social, cultural and historical origins of thought. The central process of his theory of human development is linguistic mediation. His position is unique and has illustrated by his explanation of the principle of signaling that is the creation of signs for the child.

We can highlight from the aforementioned that Vygotsky differs from Piaget's conception by stating that learning is social and based on previous ideas and experiences, these being the basis for new knowledge

\subsection{Influence of the environment for learning}

It is clear that the social context is vital in the life of each person because it is the environment in which all the educational event that influences and strongly affects development takes place. Education, as we have stated before, always takes place in the bosom of social life.

Since childhood everything is instilled in the person in the family, in school, in social treatment, in books and in-laws. A large portion of that social world that gives us education and culture becomes part of authentic 
people with identity; but beliefs, opinions, projects and tastes also arise in us that, more or less, disagree with what is in force, what is done or said in the social contexts that individuals contain before and after entering the teaching process and learning either formal or informal. (Colilef, 2012).

As you can see, people acquire lessons from the different environments that surround them and each one of them contributes to the formation of each being, that is why it is important that these environments be enriching and positive in the lives of students. (Roa, Vallejo, 2008; Martinez et al., 2019). They refer to culture in general terms, which is responsible for transforming nature to adapt it to the determined ends of man. This same transformation is verified in the cultural development of behavior, which transforms what has been given by nature, since man does not initially possess all the elements for efficient thinking, but requires the support of a social and cultural environment.

In this sense we can highlight the importance of social and cultural media in the development of the human being himself who helps him in the acquisition of new learning and in turn helps him in the configuration of behavior and contributing to the formation of a social being in table 1 the results.

Table 1

Reflection of different authors

\begin{tabular}{|c|c|c|c|}
\hline Author & Subject & Year & Results \\
\hline Acosta & $\begin{array}{l}\text { Influence of the social context in the } \\
\text { teaching-learning process in the } \\
\text { community of the popular training and } \\
\text { promotion center Juan Bosco Obrero, } \\
\text { neighborhood la Estrella, town bolivar } \\
\text { city, bogota dc }\end{array}$ & 2008 & $\begin{array}{l}\text { Analyze the influence of the context } \\
\text { social in the teaching-learning process } \\
\text { in the lives of children. }\end{array}$ \\
\hline Campoverde & $\begin{array}{l}\text { Influence of playful techniques in the } \\
\text { development of creative thinking in } \\
\text { children from } 5 \text { to } 6 \text { years of school of } \\
\text { basic education Adolfo fassio. in cm } \\
\text { campoverde campoverde mary } \\
\text { estefany }\end{array}$ & 2016 & $\begin{array}{l}\text { Refers to the importance of } \\
\text { recreational activities in the teaching } \\
\text { process as a tool that develops } \\
\text { children's creativity, and leads them to } \\
\text { create an imaginary world where they } \\
\text { are the protagonists of their own } \\
\text { learning. }\end{array}$ \\
\hline Colilef & $\begin{array}{l}\text { The influence of the sociocultural } \\
\text { context in the teaching-learning } \\
\text { process. }\end{array}$ & 2012 & $\begin{array}{l}\text { Highlights the importance of the } \\
\text { environment in the development of } \\
\text { learning in children and indicates the } \\
\text { importance of the positive } \\
\text { environment. }\end{array}$ \\
\hline Goodin & The evolution of Learning & 2013 & $\begin{array}{l}\text { The brain has the capacity to adapt } \\
\text { thanks to its plasticity. }\end{array}$ \\
\hline Jensen & Brain and Learning & $\begin{array}{l}2004 \\
\mathrm{He}\end{array}$ & $\begin{array}{l}\text { Bases his study on understanding how } \\
\text { the human brain elaborates and gives } \\
\text { meaning to the information it receives } \\
\text { and in turn builds knowledge. }\end{array}$ \\
\hline Salinas & Human Brain Project & 2016 & $\begin{array}{l}\text { The author refers to the brain and its } \\
\text { functions and how it differs from one } \\
\text { individual to another }\end{array}$ \\
\hline Velásquez & The Learning Brain & 2009 & $\begin{array}{l}\text { Describes the learning process the } \\
\text { brain as a thinking organ, how it } \\
\text { establishes its connection networks } \\
\text { Neural to create synapse. }\end{array}$ \\
\hline van Leer & Learning starts early and read & 2013 & $\begin{array}{l}\text { The child learns from his conception } \\
\text { and accumulates knowledge } \\
\text { depending on the stimulus he receives }\end{array}$ \\
\hline
\end{tabular}

Reina, A. L. V. (2019). The brain and learning on initial students. International Journal of Health Sciences, 3(2), 38-43. https://doi.org/10.29332/ijhs.v3n2.329 
Van Leer Influence of playful techniques in the development of creative thinking in the area of language and literature in students in fifth-grade education general. from his environment.

2017 The importance of the game in the acquisition of learning in children has manifested.

In the investigation it was noted that the different authors agree that the human brain is the most complex organ to understand and that this differs from one individual to another depending on the neural connections and this will be given depending on the stimuli that the individual receives from the environment, that is why the urgent task of providing positive and healthy environments arises with the purpose of consolidating meaningful and useful learning for children in children, because it can be understood in the studies that the authors express that the human being learns from that is gestating and shaping his behavior depending largely on everything he received.

\section{Conclusion}

The human brain receives the information and organizes it correctly and from there it is appropriate to store it according to the importance that it has for the individual, the brain at every moment is receiving information and evoking the stored to find new learning.

All learning begins from childhood and lasts a lifetime because at each moment you learn something new and this depends very much on the environment where it develops if this is positive will provide enriching and lasting lessons.

Recreational activities and creativity encourage meaningful learning for children as it gives them the opportunity to fantasize and create a magical world using imagination.

The environment has a lot of influence on the development of the human being and therefore on the acquisition of learning since by nature man is a social being, therefore collaborative learning will always be a powerful tool in the learning process.

\section{Acknowledgments}

We thank different teachers who have worked so that alternatives can be sought through the use of neuroscience in the teaching-learning process. 
References

Acosta. (2008). Influence of the social context in the teaching-learning process in the community of the popular training and promotion center Juan Bosco obrero, neighborhood la Estrella, town bolivar city, Bogota dc in Rosa Elena Roa Acosta. Bogota

Alava, E. E., \& Martinez, M. E. M. (2019). Impact of teaching-learning process for brain. International Journal of Health Sciences, 3(1), 33-40. https://doi.org/10.29332/ijhs.v3n1.304

Campoverde Campoverde, MS, \& Cedeño Moreira, MM (2016). Influence of playful techniques in the development of creative thinking in children from 5 to 6 years of Adolfo Fassio School of Basic Education \# 309, Zone 8, District 3, Sucre Parish, Guayaquil Canton, Guayas Province, during the 2015 Reading Period 2016 (Bachelor's thesis, University of Guayaquil Faculty of Philosophy, Letters and Education Sciences).

Colilef San Martín, FA, Díaz Fuentes, I., Gonzales Riquelme, N., \& Solorza Morales, J. (2012). The influence of the sociocultural context in the teaching-learning process.

Glejzer (2015). The biological basis of learning. in ac Claudio Glejzer, the biological bases of learning (3rd ed. ed., p. 340). Buenos Aires, Argentina: Editorial of the faculty of philosophy and letters.

Goodin, A. D. (2013). The evolution of learning: beyond neural networks. Revista chilena de neuropsicologia, 8(1), 20-25.

Iriani, D. H., Syahdan, -, \& Nuriadi, -. (2018). The effect of early English learning on psychology. International Journal of Social Sciences and Humanities, 2(1), 65-74. https://doi.org/10.29332/ijssh.v2n1.82

Jensen, E. (Ed.). (2004). Brain-compatible strategies. Corwin Press.

Mahendra, I. W. E. (2016). Contextual learning approach and performance assessment in mathematics learning. International Research Journal of Management, IT and Social Sciences, 3(3), 7-15.

Martinez, C. J. B., Vasquez, B. S. G., Martinez, M. E. M., \& Gámez, M. R. (2019). Learning problems on educational context for cascol parish. International Journal of Social Sciences and Humanities, 3(2), 145-155. https://doi.org/10.29332/ijssh.v3n2.306

Mendoza, L. R. M., Martinez, M. E. M., \& Suarez, A. M. S. (2019). The brain as a fundamental axis in learning process. International Research Journal of Engineering, IT \& Scientific Research, 5(4), 38-45. https://doi.org/10.21744/irjeis.v5n4.689

Mustika, I. W., \& Harini, G. A. (2017). increasing education of family support for decreasing depression level towards elderly. International Journal of Health Sciences, 1(3), 10-16. https://doi.org/10.21744/ijhs.v1i3.46

Salinas, D. (2018). Human Connectome Project: The American Fraud. Journal of Medical Practice and Review, 2(12).

Suarez, A. M. S., Martinez, M. E. M., \& Mendoza, L. R. M. (2019). Brain and learning. International Journal of Social Sciences and Humanities, 3(2), 128-135. https://doi.org/10.29332/ijssh.v3n2.302

Vallejo-Medina, P., Pérez-Durán, C., \& Saavedra-Roa, A. (2018). Translation, adaptation, and preliminary validation of the female sexual function index into spanish (Colombia). Archives of sexual behavior, 47(3), 797-810. https://doi.org/10.1007/s10508-017-0976-7

Van Leer (2013). Learning starts early in by read, space for children, 1-70.

Velásquez Burgos, B. M., de Cleves, N. R., \& Calle Márquez, M. G. (2009). The Brain That Learns. Tabula Rasa, (11), 329-347.

\section{Biography of Author}

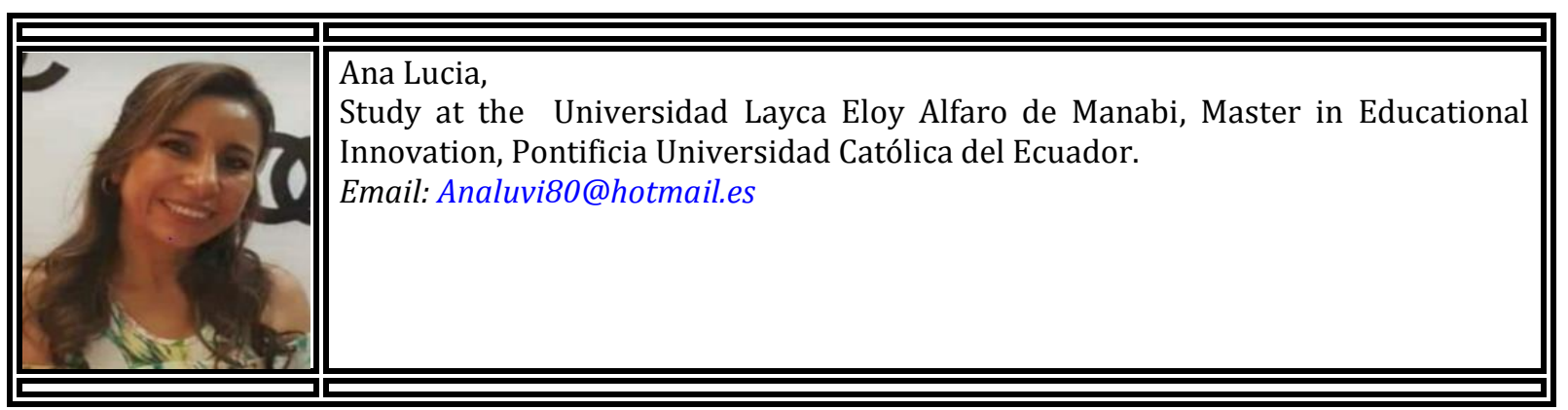

Reina, A. L. V. (2019). The brain and learning on initial students. International Journal of Health Sciences, 3(2), 38-43. https://doi.org/10.29332/ijhs.v3n2.329 